\title{
Influence of maternal experimental hypothyroidism on quantitative-qualitative indicator of rat progeny skin mast cells in age aspect according to histochemical investigation results and on the base of lectins GNA and PNA receptors cytotopography
}

\author{
Khrystyna Strus, Antonina Yashchenko*, Olena Smolkova*, Olga Nakonechna \\ Histology, Cytology, Embryology Department, Danylo Halytsky Lviv National Medical University, Lviv, Ukraine \\ Email: "yashchenko_am@ukr.net, "olenasmolkova@gmail.com \\ Received 6 June 2013; revised 6 July 2013; accepted 1 August 2013 \\ Copyright (C) 2013 Khrystyna Strus et al. This is an open access article distributed under the Creative Commons Attribution License, \\ which permits unrestricted use, distribution, and reproduction in any medium, provided the original work is properly cited.
}

\begin{abstract}
Amount of thyroid pathology patients in Ukraine increased 3.7 times from 0.9 to 3.5 per 1000 population within a decade. The main reason of most of organs damage associated with hypothyroidism is decreased synthesis of number of cellular enzymes because of thyroid hormones deficiency. Mast cells (MC) play leading role in inflammatory processes, allergic reactions and in autoimmune diseases pathogenesis, since they produce various cytokines. Influence of maternal hypothyroidism on the progeny skin histogenesis and MC correlation is poorly studied. Hypothyroid condition was modeled in Wistar female rats by adding thyreostatic drug mercazolilum (methimazole) $5 \mathrm{mg} / \mathrm{kg}$ body mass. Thyroid glands and progeny skin pieces from the back on the 1, 10, 20 and 40 postnatal development days were fixed in $4 \%$ neutral formalin and embedded in paraffin. For MC detection slides were stained by Bismark brown, alcian blue (pH 2.5), toluidine blue. D-Man and $\beta$-DGal carbohydrate determinants were studied by use of GNA and PNA lectins labeled with horseradish peroxidase. Lectin receptors visualization was conducted in 3'3-diaminobenzidine tetrahydrochloride system in $\mathrm{H}_{2} \mathrm{O}_{2}$ presence. Counting the MC number and thyroid glands' morphometric parameters were conducted on $5 \mu \mathrm{m}$ thin sections by using UTHSCSA "Image Tool for Windows Version 2.00" (USA) computer program. Statistical analysis was performed using Student ttest. Body mass increase, changes in thyroid cells parameters and colloid structure were stated in experi-
\end{abstract}

${ }^{*}$ Corresponding authors. mental animals. The biggest MC amount was detected in control animals skin on the 1 day of postnatal development, slight decrease on 10 day and gradual increase till 40 day. MC amount with signs of degranulation increased in experimental animals skin at all stages of the research. Simultaneously, D-Man and $\beta$-DGal glycopolymers expression similarity was noted on MC surface. According to MC quantitative-qualitative indicators in skin, hypothyroid female rat progeny should be included into the risk group of immune status change and allergic reactions beginning.

Keywords: Skin; Rat; Hypothyroidism; Lectin Histochemistry; Mast Cells

\section{INTRODUCTION}

Normal and pathological skin and mucosa condition are in close interaction with complicated endocrine and humoral processes. Some changes in skin and its derivatives are closely connected with endocrine disorders, and are typically manifested and have primary importance for their diagnostics and treatment $[1,2]$.

Chronic hypothyroidism causes dermis structure violations, pelage changes, sweat and sebaceous glands functional changes, skin dryness and increased exfoliation of epidermis, decrease of skin main potential, which changes physiological, immune and biochemical skin functions [3]. Various disorders from the side of cardiovascular system, central nervous system and anemia $(36 \%)$, also high percentage of skin affections $(88 \%)$ : hair loss $(40 \%)$, skin infections (22\%), skin thickening and obesity (49\%) were marked in dogs with hypothyroidism [4-7]. 
Mast cells play a leading role in inflammatory processes, allergic reactions and in autoimmune diseases pathogenesis, since they penetrate into tissues and produce various cytokines. Mast cells precursors go out from bone marrow into blood stream, whereof migrate into tissues for their maturation completing under control of cytokines and growth factors [8]. Those cells are important for both natural and gained immunity in tissues, which are in close contact with environment, namely skin and respiratory system organs [9]. There are reports about skin mast cells in literature [10-14], maternal hypothyroidism influence on quantitative-qualitative indicators of progeny skin mast cells is not investigated.

Aim of work - using routine histochemical methods to investigate quantitative ratio of mast cells in rat progeny skin under the influence of experimental hypothyroidism in age aspect and on the base of lectin-receptor interaction to study those cells glycoconjugates.

\section{MATERIALS AND METHODS}

Experiments were carried out on 20 Wistar line females, with mass $180-200 \mathrm{~g}$, which were divided into two groups: first - control (10), second - experimental (10), from which was received progeny in the amount of 35 and 30 respectively. Animals were kept in standard vivarium conditions according to the bioethics norms for dealing with laboratory animals. Experimental hypothyroidism was modeled by adding thyreostatic drug mercazolilum (Zdorovia, Kharkiv) (methimazole) at the rate of $5 \mathrm{mg} / \mathrm{kg}$ body mass. After second week of experiment females, at the estrus stage, were planted on males. Skin pieces from the back side of female control and experimental progeny on the $16^{\text {th }}$ day of embryogenesis and on the $1^{\text {st }}, 10^{\text {th }}, 20^{\text {th }}$ and $40^{\text {th }}$ days of postnatal development, were taken, fixed in $4 \%$ neutral formalin, embedded in paraffin. Function control of females thyroid gland was performed by determining $T_{3}$ and $T_{4}$ hormones in blood serum using radiological method by means of standard sets in radioisotope laboratory of regional clinical hospital, and also progeny was weighed on the appropriate terms of postnatal development. General histological and morphometric investigations of females and their progeny thyroid glands were conducted by using UTHSCSA "Image Tool for Windows. Version 2.00" (USA) computer program. Mast cells amount counting was done on the standard area of section (eyeglass $\times 10$, objective lens $\times 40$ ) on five slides $5-7 \mu \mathrm{m}$ thin, stained by aldehyde fuchsine, alcian blue (pH 2.5), Bismark brown, and on five semifine sections, stained by toluidine blue $[15,16]$. Revision of histological slides was performed by using ZEISS 470600-9901 microscope at magnification $\times 400$ and $\times 600$.

By means of lectin-peroxidase technique using two lectins: snowdrop (GNA), specific to $\alpha \mathrm{DMan}$ and peanut (PNA), specific to $\beta$-DGal, which were produced in Laboratory "Lectinotest" of Danylo Halytsky Lviv National Medical University, rat progeny skin mast cells were studied on the appropriate days of postnatal development in the norm and on the base of maternal hypothyroidism. Lectin receptors visualization was conducted in 3'3-diaminobenzidine tetrahydrochloride system in $\mathrm{H}_{2} \mathrm{O}_{2}$ presence [17]. For specificity control of histochemical reactions were used: 1) lectin-peroxidase conjugates exclusion from staining protocol; 2) before lection solution application, for oxidation of glycopolymers carbohydrate determinants, pre-incubation of histological slides was conducted during $60 \mathrm{~min}$ in $1 \% \mathrm{HIO}_{4}$ (Reanal, Budapest, Hungary). In the $1^{\text {st }}$ case histochemical reaction results were completely negative, in the $2^{\text {nd }}-$ essentially reduced. Besides abovementioned, negative staining of separate cell compartments on the base of lectinreactive structures served as peculiar control of reaction specificity.

\section{RESULTS AND THEIR DISCUSSION}

Conducted investigations of experimental group female rats thyroid glands showed, that macroscopically thyroid glands increased by $2-3$ times in comparison with control group, microscopically-thyroid follicles acquired irregular folded shape, did not contain colloid or it was present in small amounts, thyroid cells hyperplasia and harsh hyperemia of organ were detected. Similar results of thyroid glands morphology in the norm and in experimental hypothyroidism, induced by mercazolilum (methimazole) injection $(5 \mathrm{mg} / \mathrm{kg}$ ) observed [18].

Besides, thyroid cells height also changed. So, in control group females thyroid cells height was $9.31 \pm 0.49$, whereas in experimental animals height of those cells was $13.29 \pm 0.29, \mathrm{p}<0.001$.

On the base of changed concentration of hormones level in experimental females blood serum $\left(\mathrm{T}_{3}\right.$ from 1.16 \pm 0.11 to $1.04 \pm 0.13 \mathrm{nmol} / \mathrm{l}, \mathrm{p}<0.01$; and $\mathrm{T}_{4}$ from 50.0 $\pm 3.39 \mathrm{nmol} / 1$ to $4.67 \pm 3.6 \mathrm{nmol} / 1, \mathrm{p}<0.01$ ) [16], also, in progeny of hypothyroid females, morphology changes of thyroid glands were observed on the $1^{\text {st }}, 10^{\text {th }}, 20^{\text {th }}$ and $40^{\text {th }}$ days of postnatal development. Thyroid cells height also changed (Table 1 and Figure 1).

On the $16^{\text {th }}$ day of embryonic development mast cells in skin are absent, both in control progeny and in hypothyroid females progeny. We stated mast cells appearance on the $1^{\text {st }}$ day of postnatal development. Mast cells are mostly localized around microcirculatory flow vessels, in reticular layer of the dermis. Part of these cells is in degranulation stage (Figure 2). On the $20^{\text {th }}$ day of postnatal development significant number of mast cells was detected closer to epidermis in experimental animal progeny skin. 


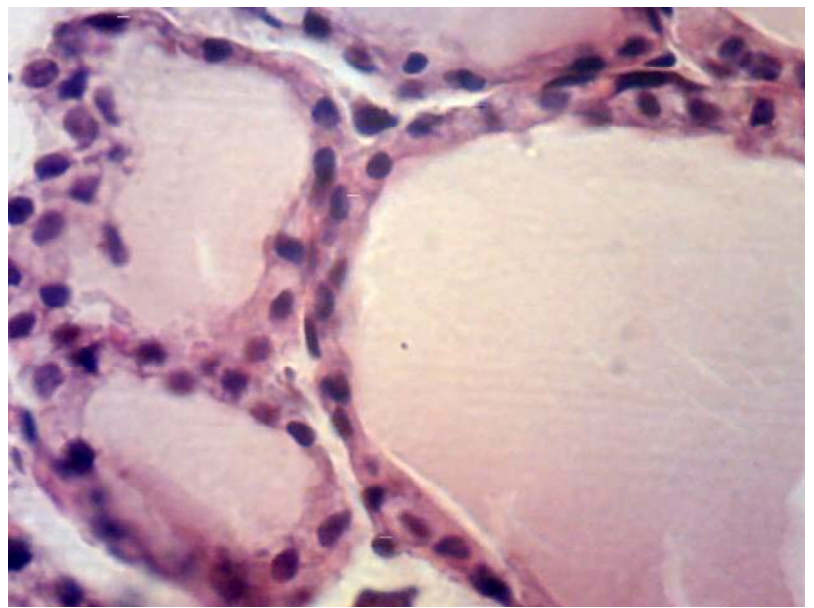

(a)

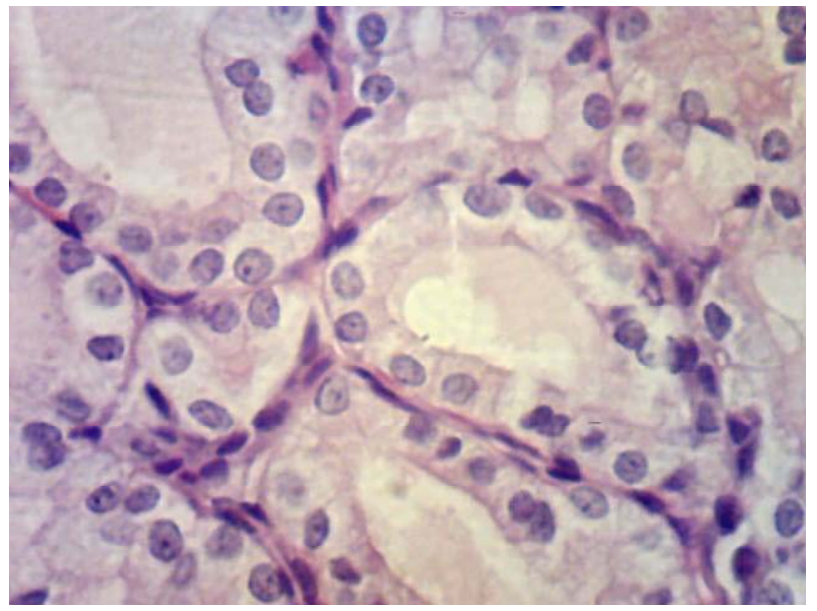

(b)

Figure 1. Thyroid gland morphology of rat progeny on the $40^{\text {th }}$ day of postnatal development. Staining by hematoxylin and eosin. (a) Thyroid gland follicles of control progeny. Magnif. $\times 600$; (b) Thyroid gland follicles of progeny of hypothyroid females. Magnif. $\times 600$.

Table 1. Thyroid cells height of control and hypothyroid progeny on the $1^{\text {st }}, 10^{\text {th }}, 20^{\text {th }}$ and $40^{\text {th }}$ days of postnatal development $(\mu \mathrm{m})$.

\begin{tabular}{cccc}
\hline \multirow{2}{*}{ Animal groups } & Control & \multicolumn{2}{c}{ Experiment } \\
\cline { 2 - 4 } & $\mathbf{M} \pm \mathbf{m}$ & $\mathbf{M} \pm \mathbf{m}$ & $\mathbf{p}$ \\
\hline $\mathbf{1}^{\text {st }}$ day & $6.97 \pm 0.10$ & $8.48 \pm 0.06$ & $<0.001^{\text {*** }}$ \\
$\mathbf{1 0}^{\text {th }}$ day & $7.27 \pm 0.06$ & $9.40 \pm 0.05$ & $<0.001^{\text {*** }}$ \\
$\mathbf{2 0}^{\text {th }}$ day & $8.29 \pm 0.10$ & $9.57 \pm 0.07$ & $<0.001^{\text {*** }}$ \\
$\mathbf{4 0}^{\text {th }}$ day & $8.49 \pm 0.05$ & $9.60 \pm 0.07$ & $<0.001^{\text {**** }}$ \\
\hline
\end{tabular}

"*** means "highly reliable" $(\mathrm{p}<0.001),{ }^{* *}$ means "reliable" $(\mathrm{p}<0.01),{ }^{*}$ means "unreliable".

Mast cells amount counting in different fields of view in histological slides, stained by histochemical methods, showed gradual increase of their quantity from $10^{\text {th }}$ to $40^{\text {th }}$ day of postnatal development in control group rat progeny skin (from $13.08 \pm 0.98$ to $16.44 \pm 0.36$ ). Ratio results of mast cells amount are given in Table 2 and on Figure 3.

In return, in control group rat progeny skin decrease of mast cells amount was noted (from $24.08 \pm 0.73, \mathrm{p}<$ 0.001 to $16.16 \pm 0.34, \mathrm{p}=0.87$ ) from $1^{\text {st }}$ till $40^{\text {th }}$ day of

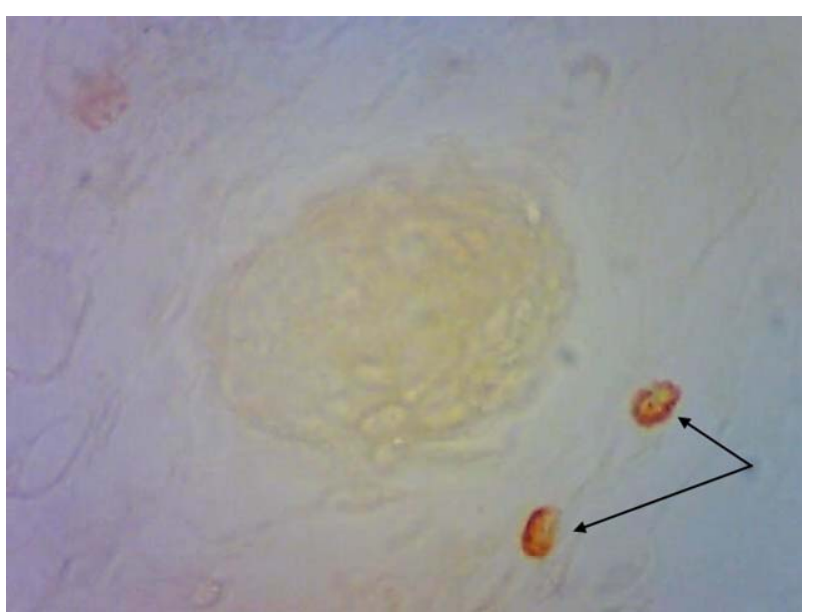

(a)

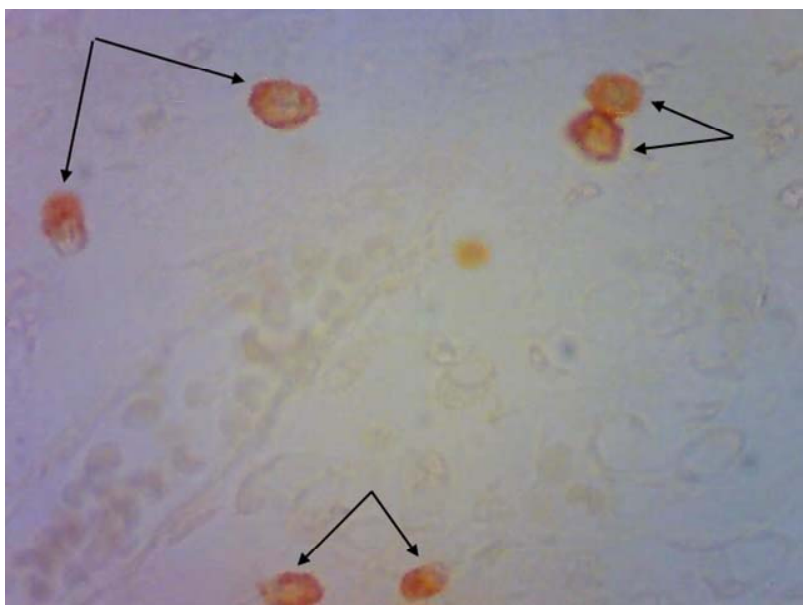

(b)

Figure 2. Rat progeny skin on the $1^{\text {st }}$ day of postnatal development. Staining by Bismark brown. Arrows show mast cells. (a) Mast cells in skin dermis of progeny of control females. Magnif. $\times 600$; (b) Mast cells amount increase in skin dermis of progeny of hypothyroid females. Magnif. $\times 600$.

Table 2. Mast cells amount in progeny skin of control and hypothyroid females.

\begin{tabular}{cccc}
\hline \multirow{2}{*}{ Animal groups } & Control & \multicolumn{2}{c}{ Experiment } \\
\cline { 2 - 4 } & $\mathbf{M} \pm \mathbf{m}$ & $\mathbf{M} \pm \mathbf{m}$ & $\mathbf{p}$ \\
\hline $\mathbf{1}^{\text {st }}$ day & $17.0 \pm 1.11$ & $24.08 \pm 0.73$ & $<0.001^{\text {****}}$ \\
$\mathbf{1 0}^{\text {th }}$ day & $13.08 \pm 0.98$ & $21.84 \pm 0.94$ & $<0.001^{* * *}$ \\
$\mathbf{2 0}^{\text {th }}$ day & $14.28 \pm 0.13$ & $18.48 \pm 0.39$ & $<0.01^{* *}$ \\
$\mathbf{4 0}^{\text {th }}$ day & $16.44 \pm 0.36$ & $16.16 \pm 0.34$ & $=0.87$ \\
\hline
\end{tabular}

*** means "highly reliable" $(\mathrm{p}<0.001),{ }^{* *}$ means "reliable" $(\mathrm{p}<0.01),{ }^{*}$ means "unreliable". 
postnatal development. When comparing mast cells investigation results of control and hypothyroid female progeny skin, we noticed, that latter amount in experimental groups was slightly larger, so for example, on the $1^{\text {st }}$ day of postnatal development in experimental groups was equal to $17.0 \pm 1.11$, while in experiment their amount increased to $24.08 \pm 0.73, \mathrm{p}<0.001$. Increase in their amount was also observed on the $10^{\text {th }}$ and $20^{\text {th }}$ days of postnatal development, but on $40^{\text {th }}$ day these cells amount hardly differed in progeny skin of control and experimental animals (Table 2 and Figures 3-5). Mast cells counting showed the wave-like increase of their amount with further stabilization on the $40^{\text {th }}$ day of postnatal development (Figure 3).

Mast cells are on of starting effector of inflammation and source of large amount of inflammation initial mediators, such as histamine, serotonin (in small rodents), cysteine leukotrienes, prostaglandins (mainly $\mathrm{D}_{2}$ ), factor which activates trombocytes, numerous enzymes et al. Because of this mast cells largely detect further events in mediator cascade and in intercellular interactions in focus [9]. That is why, mast cells quantity increase in maternal hypothyroidism certifies, that high risk of allergic reactions development exists in the period before puberty. Probably, gradual decrease in difference of mast cells amount with age is connected with processes of adaptation to environment and transition to independent way of feeding. Such phenomenon may be connected also with decrease of immune status as the answer to hypothyroid condition and mast cells ratio in control and experimental animals. Changes in immune status during hypothyroidism also noted [3].

Previously conducted by us lectin histochemical investigations of progeny skin slides of different age groups showed, that lectins (SNA, WGA, PNA, HPA, Con A and LABA) binded with structural components of skin, epidermis (stratum corneum), with structural components of hair (cortex and medulla), with dermis fiber

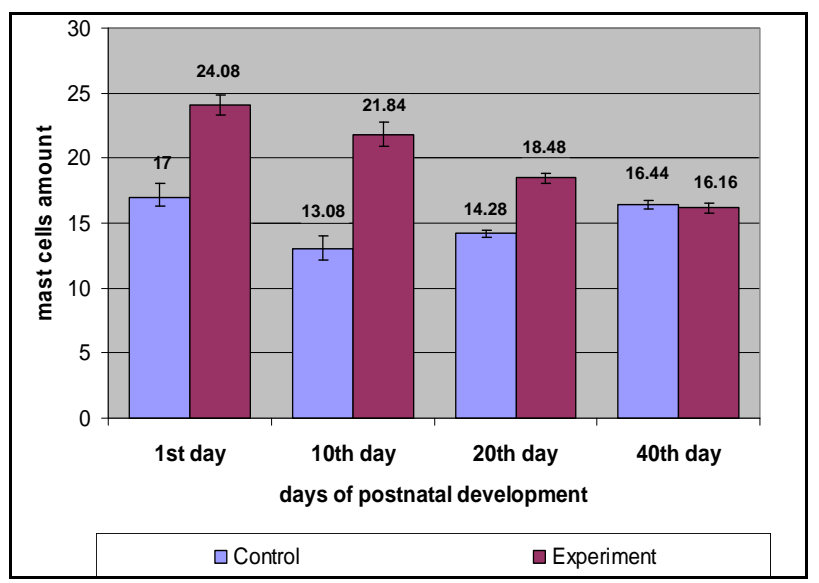

Figure 3. Ratio of mast cells amount in progeny skin of control and hypothyroid rat females.

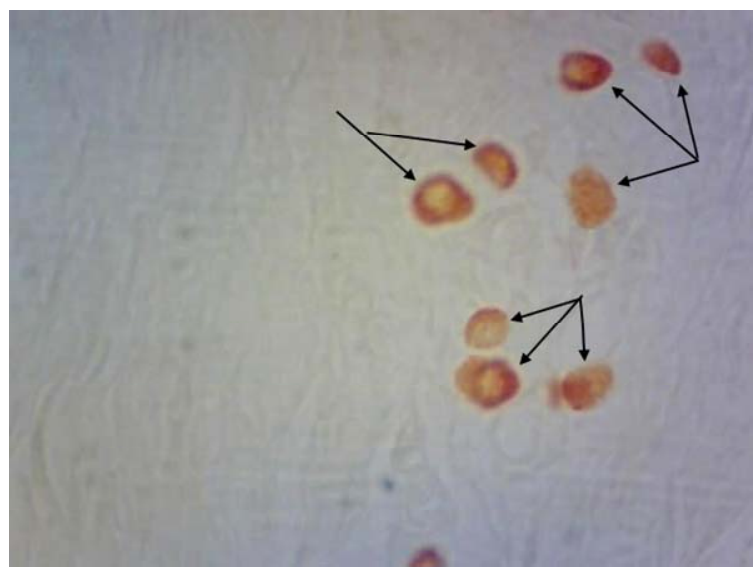

(a)

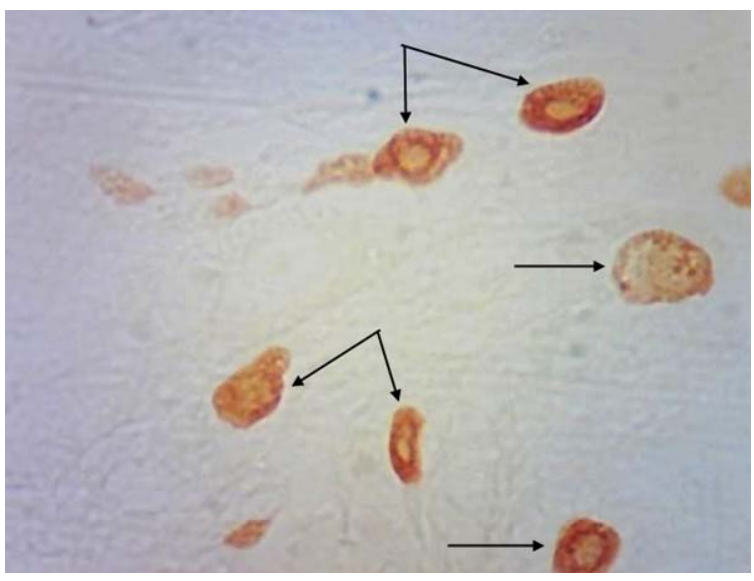

(b)

Figure 4. Rat progeny skin on the $40^{\text {th }}$ day of postnatal development. Staining by Bismark brown. Arrows show mast cells. (a) Mast cells in skin dermis of progeny of control females. Magnif. $\times 600$; (b) Mast cells in skin dermis of progeny of hypothyroid females. Magnif. $\times 600$.

structures, with cell surface of sebaceous glands [19,20].

Along with this, exhibiting of GNA mannose-specific lectin was certified on the mast cells surface of animal progeny skin of control and experimental group (Figure 6).

It is known, that important role in cell functioning providing belongs to mannose- and fucoseglycans [21]. Mast cells have receptors to antibodies, which belong to class E immunoglobulins (IgE) [22]. Probably, glycoconjugates as $\alpha$ DMan ensure adhesive properties of immunoglobulins in response to antigens, intensified exhibiting of GNA lectin receptors probably point to their increased functional activity.

Besides GNA lectin receptors, we detected exhibiting of PNA lectin receptors in mast cells cytoplasm. Similar binding of this lectin with mast cells surface of salivary glands stroma of rat progeny was detected by [23]. GNA and PNA lectins, used by us, can be considered as markers of rat skin mast cells. 


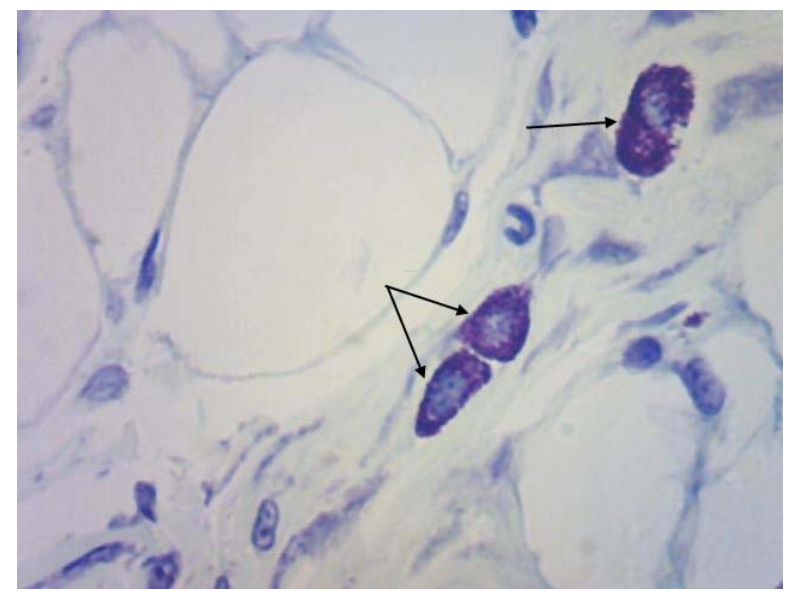

(a)

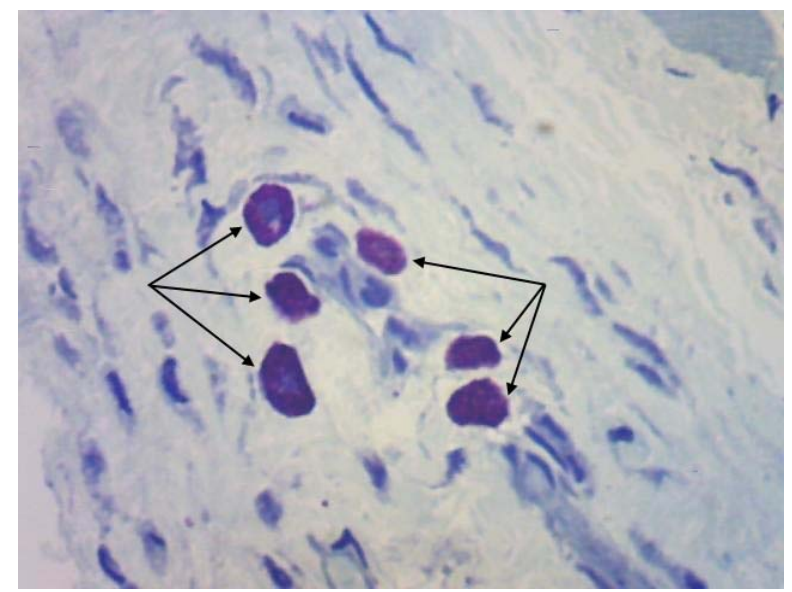

(b)

Figure 5. Rat progeny skin on the $40^{\text {th }}$ day of postnatal development. Semifine section. Staining by toluidine blue. Arrows show mast cells. (a) Mast cells in skin dermis of progeny of control females. Magnif. $\times 600$; (b) Mast cells in skin dermis of progeny of hypothyroid females. Magnif. $\times 600$.

\section{CONCLUSIONS}

1) On the background of female hypothyroidism morphofunctional changes in progeny thyroid glands were observed, as evidenced by the morphological change in gland structural components and thyroid cells morphometric parameters. In progeny skin of control animals the largest amount of mast cells has been observed on the $1^{\text {st }}$ day of postnatal development with further insignificant decrease on the $10^{\text {th }}$ day and their gradual increase till $40^{\text {th }}$ day.

2) Under the influence of maternal hypothyroidism the increase of mast cells amount is observed in progeny skin comparatively to control from the $1^{\text {st }}$ to $20^{\text {th }}$ days, with gradual decrease on the $40^{\text {th }}$ day to indicators in control group. Till $40^{\text {th }}$ day of postnatal development, according to the mast cells amount, progeny of rat hypothyroid females can be included into the risk group of immune status change and allergic reactions beginning.

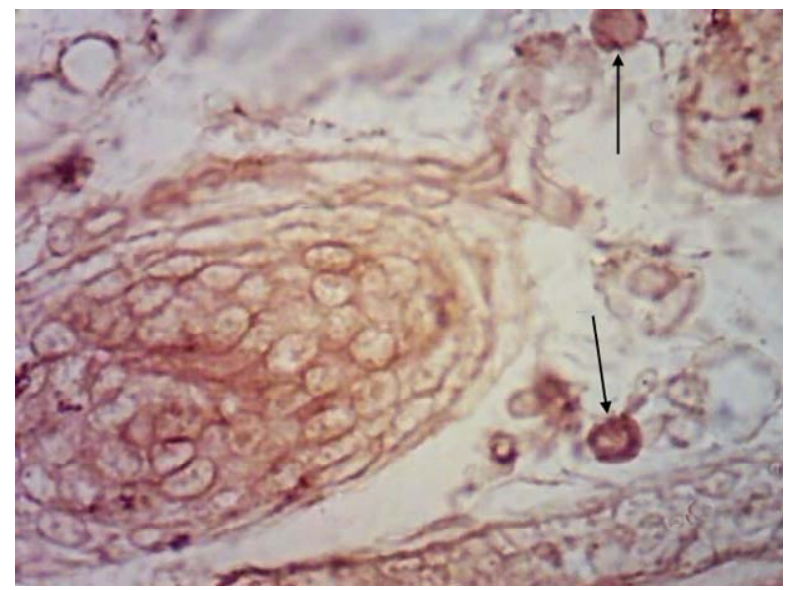

(a)

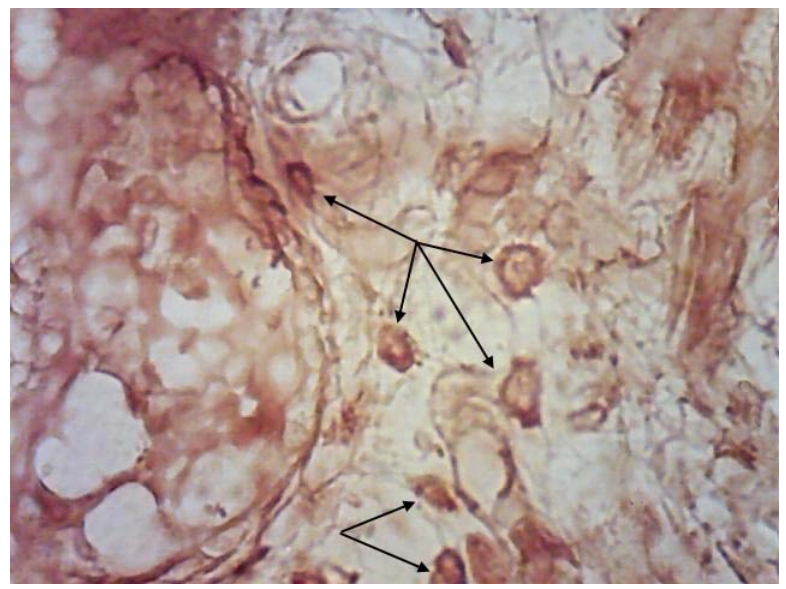

(b)

Figure 6. Rat progeny skin on the $10^{\text {th }}$ day of postnatal development. Semifine section. Arrows show mast cells. (a) GNA lectin receptors on mast cells surface in progeny skin of control females. Magnif. $\times 600$; (b) GNA lectin receptors on mast cells surface in progeny skin of hypothyroid females. Magnif. $\times 600$.

\section{PERSPECTIVES OF FURTHER INVESTIGATIONS}

In perspective more detailed study of tropism of lectins with different carbohydrate specificity to mast cells of rat progeny skin is planned.

\section{REFERENCES}

[1] Ivanov, O.L. and Lomonosov, K.M. (2003) Skin changes in pathology of internal organs (dermatoms). Therapeutic Archive, 1, 77-80.

[2] Popov, L. (1963) Synthetic dermatology. Medicina i Fiskultura, Sofia.

[3] Purysheva, V.I., Kudokoceva, O.V., Volina, V.V., et al. (2009) Premature aging of skin, caused by hypothyroidism, and methods of its correction. Bukovynsky Medical Herald, 13, 236-239. 
[4] Bojanic, K., Acke, E. and Jones, B.R. (2011) Congenital hypothyroidism of dogs and cats: A review. New Zealand Veterinary Journal, 59, 115-122. doi: $10.1080 / 00480169.2011 .567964$

[5] Boretti, F.S., Breyer-Haube, I., Kaspers, B. and Reusch, C.E. (2003) Clinical, hematological, biochemical and endocrinological aspects of 32 dogs with hypothyroidism. Schweizer Archiv für Tierheilkunde, 145, 149-156, 158159. doi:10.1024/0036-7281.145.4.149

[6] McKeown, H.M. (2002) Hypothyroidism in a boxer dog. Canadian Veterinary Journal, 43, 553-555.

[7] Scott-Moncrieff, J.C. (2007) Clinical signs and concurrent diseases of hypothyroidism in dogs and cats. Veterinary Clinics of North America: Small Animal Practice, 37, 709-722. doi:10.1016/j.cvsm.2007.03.003

[8] Sarah, J., Collington, S.J., Williams, T.J. and Charlotte, L. (2011) Mechanisms underlying the localisation of mast cells in tissues. Trends in Immunology, 32, 478-485. doi:10.1016/j.it.2011.08.002

[9] Tete, S., Tripodi, D., Rosati, M., et al. (2012) Role of mast cells in innate and adaptive immunity. Journal of Biological Regulators \& Homeostatic Agents, 26, 193201.

[10] Harvima, I.T. and Nilsson, G. (2012) Stress, the neuroendocrine system and mast cells: Current understanding of their role in psoriasis. Expert Review of Clinical Immunology, 8, 235-241. doi:10.1586/eci.12.1

[11] González-Elorriaga, M.A. and Canepa, G. (2002) The tongue mast cells of Bufo marinus L. toad: Characterization of glycoconjugates with conventional and lectin methods. Acta Cientifica Venezolana, 53, 183-194.

[12] North, S.J., von Gunten, S., Antonopoulos, A., et al. (2012) Glycomic analysis of human mast cells, eosinophils and basophils. Glycobiology, 22, 12-22. doi:10.1093/glycob/cwr089

[13] Metz, M., Siebenhaar, F. and Maurer, M. (2008) Mast cell functions in the innate skin immune system. Immuno- biology, 213, 251-260. doi:10.1016/j.imbio.2007.10.017

[14] Roberts, I.S., Jones, C.J. and Stoddart, R.W. (1990) Lectin histochemistry of the mast cell: Heterogeneity of rodent and human mast cell populations. Histochemical Journal, 22, 73-80. doi:10.1007/BF01885784

[15] Lupa, K. (1980) The bases of histochemistry/Kh. Lupa. Mir, Moscow.

[16] Shubych, M.G. (1961) Method of elective staining of acid (sulfated) mucopolysaccharides by Bismark brown. Bulletin of Experimental Biology and Medicine, 51, 116-120.

[17] Lutsyk, A.D., Detiuk, Y.S. and Lutsyk, M.D. (1989) Lectins in histochemistry. Vysha Shkola, Lvov.

[18] Lutsyk, S.O. and Yashchenko, A.M. (2012) Experimental hypothyroidism causes intensified exhibiting of carbohydrate determinants $\alpha$ LFuc, $\beta$ DGal and DGalNAc in rat adrenal glands. World Medical Biology, 2, 123-128.

[19] Preima, K.I. and Yashchenko, A.M. (2009) Glycoconjugates role in processes of morphogenesis of rat progeny skin on the background of maternal hypothyroidism. Bukovynsky Medical Herald, 4, 232-236.

[20] Preima, K.I. and Yashchenko, A.M. (2010) Cytotopography of lectin receptors instructural components of skin and its derivatives in progeny of control and hypothyroid rat females according to data of lectin histochemistry. Herald of Morphology, 16, 409-416.

[21] Sharon, N. (2007) Lectins: Carbohydrate-specific reagents and biological recognition molecules. The Journal of Biological Chemistry, 282, 2753-2764. doi:10.1074/JBC.X600004200

[22] Carr, T.F. and Saltoun, C.A. (2012) Chapter 2: Skin testing in allergy. Allergy and Asthma Proceedings, 33, 3-8. doi:10.2500/aap.2012.33.3532

[23] Lutsyk, A.D., Yashchenko, A.M. and Detiuk, Y.S. (1987) Lectin binding by structures of rat submandibular salivary gland in postnatal ontogenesis at thyroid pathology. Archive of Anatomy, Histology and Embryology, 92, 40-48. 